\title{
ANALISA KUALITAS PERAIRAN DITINJAU DARI TINGKAT SAPROBITAS DAN KANDUNGAN KLOROFIL DI MUARA SUNGAI BODRI KENDAL
}

\author{
Analysis of Water Quality Based on Saprobity Level and Chlorophyl Contents \\ in Bodri River Estuary, Kendal
}

\author{
Okky Aditya Ramanda, Bambang Sulardiono *) dan Churun Ain \\ Program Studi Manajemen Sumberdaya Perairan, Departemen Sumberdaya Akuatik, \\ Fakultas Perikanan dan Ilmu Kelautan, Universitas Diponegoro \\ Jl. Prof. H. Soedharto, SH, Tembalang Semarang 50275, Telp/Fax (024) 7474698 \\ Email : adityaramand1245@gmail.com
}

\begin{abstract}
ABSTRAK
Penelitian ini bertujuan untuk mengetahui nilai saprobitas perairan (SI dan TSI), kandungan klorofil perairan, dan hubungan antara SI, TSI dengan kualitas perairan. Penelitian dilaksanakan pada bulan Agustus 2016 dengan materi yakni sampel air dari Muara Sungai Bodri dan metode deskriptif serta metode pengambilan sampel yakni Purposive Sampling Method. Sampling dilakukan dengan pengulangan waktu yakni pasang dan surut dengan 3 kali pengulangan dengan 4 Stasiun lokasi sampling. Hasil penelitian didapatkan 65 genera dengan 115 spesies yang didominasi oleh Bacillariophyceae seperti Synedra sp., Skeletonema sp., dan Asterionella sp. Kelimpahan fitoplankton tertinggi terjadi pada Stasiun 1 saat surut sebesar 85184 ind/L yang didominasi oleh Synedra ulna. Dari hasil penelitian didapatkan nilai SI pada kisaran 0.75-1.29 yang menyatakan perairan dalam kondisi $\beta$-Mesosaprobik hingga $\beta$ Mesosaprobik/Oligosaprobik. Sedangkan, untuk TSI didapatkan nilai 0.99-2.56 yang menyatakan perairan dalam kondisi $\beta$-Mesosaprobik hingga Oligosaprobik. Hasil pengukuran kadar klorofil- $\alpha$ menunjukkan bahwa klorofil- $\alpha$ pada wilayah di sekitar muara bernilai rendah. Hubungan antara nilai SI dan TSI dengan kualitas perairan menunjukkan nilai positif dengan keeratan lemah pada saat pasang serta nilai positif dan negatif dengan keeratan kuat pada saat surut.
\end{abstract}

Kata Kunci : Muara Sungai Bodri; Klorofil- $\alpha$; Indeks Saprobik; Tropik Saprobik Indeks

\section{ABSTRACT}

This study aims to determine the value of water saprobity (SI and TSI), chlorophyl- $\alpha$ content and the context of SI, TSI with water quality such as DO, TSS, Nitrate and chlorophyl- $\alpha$ in Bodri River Estuary. This study was conducted in August 2016. The material used in this study is a sample of water taken from Bodri Estuary. The method used in this study is descriptive method with also sampling method is Purposive Sampling. The sampling location consisted by 4 stasions and it done with repetition time of the high and low tide. The result showed 65 genera with 115 species dominated by Bacillariophyceae such as Synedra sp., Skeletonema sp. and Asterionella sp. The highest phytoplankton abundance occurs in Station 1 at low tide at value 85184 ind/L which dominated by Synedra ulna. SI values in the range 0.75-0.29 which states that the water in $\beta$-Mesosaprobic to $\beta$-Mesosaprobic/Oligosaprobic conditions. While using TSI, it obtained values at range 0.99-2.56 which it states that the water in $\beta$-Mesosaprobic to Oligosaprobic conditions. The results of clorophyl- $\alpha$ measurement showed that the chlorophyl- $\alpha$ in the area around the estuary at a low value. The connection between SI and TSI with water quality has a positive value with weak correlaion at high tide and positive and negative value with strong correlation at low tide.

Keywords: Bodri River Estuary; Chlorophyl- $\alpha$; Saprobic Index; Trophic Saprobic Index

\section{*) Penulis Penanggungjawab}

\section{PENDAHULUAN}

Muara merupakan wilayah dengan percampuran dua arus dari sungai dan laut yang menyebabkan fluktuasi salinitas pada daerah tersebut. Aktivitas manusia di sekitar muara sangat mempengaruhi ekosistem muara dikarenakan beban bahan organik yang terbawa oleh arus sungai dapat menyebabkan pengkayaan nutrien. Masuknya bahan organik ke pesisir ini cepat atau lambat akan mempengaruhi kualitas perairan, selanjutnya akan berpengaruh pada keberadaan organisme perairan khususnya plankton sebagai organisme yang pertama merespon perubahan kualitas perairan tersebut. Beban masukan yang nyata biasanya membawa partikel tersuspensi, nutrien dan bahan organik terlarut yang akan mendukung terjadinya eutrofikasi dan bisa menyebabkan berkurangnya penetrasi cahaya pada kolom air (Cervetto et al., 2002). 
Muara Sungai Bodri merupakan sungai dengan masukan limbah organik yang berasal dari kegiatan pertanian, pertambakan dan perikanan. Dengan masuknya limbah ke perairan, struktur komunitas plankton dan kualitas perairan akan mengalami perubahan sesuai dengan pengaruh cuaca dan pasang surut. Davies (2004) mengemukakan bahwa besarnya jumlah unsur hara dalam aliran sungai tergantung pada curah hujan, luas daerah aliran sungai (DAS), dan intensitas penduduk pada daerah aliran sungai. Faktor lain yang mempengaruhi besaran suplai bahan organik ke perairan yaitu kondisi musim. Pada musim penghujan jumlah suplai nutrien besar dan pada musim kemarau jumlah suplai nutrien kecil.

Saprobitas perairan adalah keadaan kualitas air yang diakibatkan adanya penambahan bahan organik dalam suatu perairan yang biasanya indikatornya adalah jumlah dan susunan spesies dari organisme dalam perairan tersebut (Abadi et al. 2014). Nilai saprobitas ditentukan oleh keberadaan indikator perairan yakni plankton sebagai indikasi kesuburan perairan. Pengunaan fitoplankton sebagai indikator didasarkan pada faktor pertumbuhan plankton yang dapat dipicu oleh nutrien dan bahan organik. Selain itu, kualitas perairan juga mempengaruhi faktor pertumbuhan fitoplankton dan pasang surut. Sachlan (1982) dalam Rahman dan Purnamaningtyas (2012) menyebutkan bahwa plankton mempunyai kepekaan dan toleransi yang berbeda-beda terhadap bahan pencemar, sehingga dapat dijadikan indikator perubahan kualitas lingkungan perairan.

Penelitian ini bertujuan untuk mengetahui kategori saprobitas, kandungan klorofil- $\alpha$ dan hubungan antara SI dan TSI dengan kualitas perairan yakni DO (Oksigen Terlarut), Nitrat, TSS (Total Suspended Solid) dan klorofil- $\alpha$ di Muara Sungai Bodri, Kendal.

\section{MATERI DAN METODE PENELITIAN}

\section{A. Materi Penelitian}

Materi penelitian ini adalah sampel plankton (fitoplankton dan zooplankton) yang diambil dari masing-masing stasiun di Muara Sungai Bodri. Beberapa variabel kualitas perairan meliputi suhu, $\mathrm{pH}, \mathrm{DO}$, kecepatan arus, kecerahan, salinitas, nitrat, TSS dan klorofil- $\alpha$. Alat yang digunakan untuk pengambilan sampel plankton dan pengukuran kualitas air yakni ember $10 \mathrm{~L}$, plankton net no. 25, botol sampel $100 \mathrm{ml}$ secchi disk, meteran jahit, termometer air raksa, kertas $\mathrm{pH}$, stopwatch, refraktometer, pipet tetes, gelas ukur, kotak es, bola arus, tali rafia, GPS, botol Winkler $250 \mathrm{ml}$ dan tabung erlenmeyer. Alat yang digunakan dalam identifikasi pada laboratorium yakni cawan Sedgewick Rafter, spektrofotometer, kertas saring, sentrifuge, oven, desikator kabinet, timbangan elektrik, mikroskop dengan perbesara 4x10. Bahan yang digunakan dalam penelitian ini adalah sampel plankton dan sampel air yang didapat dari Muara Sungai Bodri, aquades, lugol $1 \%$, buku identifikasi plankton, reagen kit nitrat, aseton $90 \%$, $\mathrm{MnSO}_{4}, \mathrm{KOH}-\mathrm{KI}_{2} \mathrm{H}_{2} \mathrm{SO}_{4}$ pekat, amilum $1 \%$ dan $\mathrm{Na}_{2} \mathrm{~S}_{2} \mathrm{O}_{3}$.

\section{B. Metode Penelitian}

Metode yang digunakan dalam penelitian ini adalah metode deskriptif yang bersifat studi kasus. Menurut Hutabarat et al. (2013) yang dimaksud studi kasus adalah studi yang mempelajari objek secara mendalam pada waktu, tempat dan populasi yang terbatas sehingga memberikan gambaran tentang situasi dan kondisi secara lokal dan hasilnya tidak berlaku untuk tempat dan waktu yang berbeda.

\section{Penentuan lokasi sampling}

Teknik penentuan lokasi menggunakan metode Purposive Sampling yang didasarkan pada beberapa pertimbangan seperti ruang (letak stasiun di sekitar muara) dan waktu (kondisi pasang surut). Menurut Teddlie \& Yu (2007), teknik Purposive Sampling (sampel bertujuan), biasa digunakan dalam penelitian kualitatif, yaitu ditentukan dengan cara pemilihan unit terlebih dahulu (misalnya individual, kelompok individu, atau institusi) didasarkan pada tujuan spesifik terkait dengan jawaban dari pertanyaan penelitian. Lokasi pengambilan sampel terbagi ke dalam 4 Stasiun yakni Stasiun 1 (Sungai), Stasiun 2 (Muara), Stasiun 3 (Muara ke arah laut sebelah kiri) dan Stasiun 4 (Muara ke arah laut sebelah kanan). Pada tiap-tiap stasiun dilakukan 3 kali pengulangan dengan interval pada saat pagi (pasang) dan sore hari (surut)

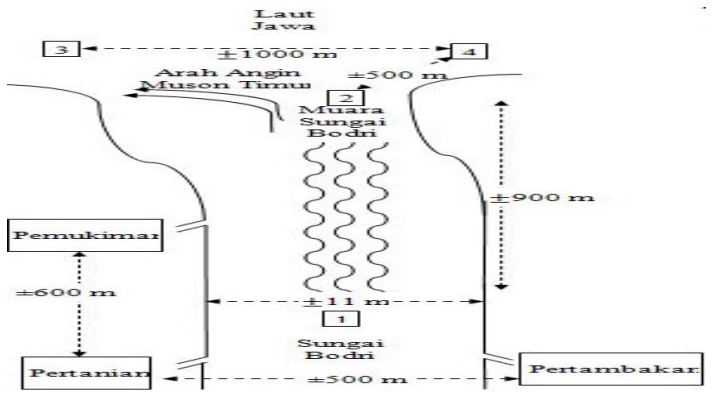

Teknik pengambilan sampel

Gambar 1. Layout lokasi penelitian di Muara Sungai Bodri

Pengambilan sampel dilakukan secara pasif dengan menyaring air sebanyak $100 \mathrm{~L}$ yang diambil dengan menggunakan ember $10 \mathrm{~L}$ dan disaring menggunakan plankton net no. 25. Sampel air hasil penyaringan dimasukkan ke dalam botol sampel kemudian diberi larutan lugol $1 \%$ sebanyak $1 \mathrm{ml}$. 


\section{Pengukuran kualitas perairan}

Pengukuran DO dilakukan dengan metode titrasi dengan cara mengambil air sampel dengan menggunakan botol Winkler dengan penambahan $1 \mathrm{ml} \mathrm{MnSO}_{4}$ dan $1 \mathrm{ml} \mathrm{KOH-KI}$ hingga larutan homogen. Kemudian, dilakukan penambahan $\mathrm{H}_{2} \mathrm{SO}_{4}$ pekat sebanyak $1 \mathrm{ml}$ hingga muncul endapan berwarna coklat kekuningan. Lalu, ambil $100 \mathrm{ml}$ ke dalam tabung erlenmeyer dan dilakukan penambahan amilum 3-5 tetes hingga berwarna biru tua. Setelah itu, titrasi dengan $\mathrm{Na}_{2} \mathrm{~S}_{2} \mathrm{O}_{3} 0,025 \mathrm{~N}$ hingga warna biru tersebut hilang/jernih dan catat penggunaan larutan titrasi.

Berikut rumus perhitungan DO menurut SNI, (2004) yakni sebagai berikut:

DO $(\mathrm{mg} / 1)=\frac{\text { ml titran } \times \mathrm{N} \text { titran } \times 8 \times 1000}{\mathrm{ml} \text { sampel }}$

Keterangan:

$\mathrm{ml}$ titran $=$ volume zat yang akan diukur

$\mathrm{N}$ titran $\quad=$ konsentrasi zat yang diukur

$\mathrm{ml}$ sampel $=$ jumlah sampel yang diukur

Pengukuran nitrat menggunakan alat spektrofotometer dengan memasukkan sampel $25 \mathrm{ml}$ dan sampel $25 \mathrm{ml}$ air yang telah diionisasi. Pada tiap botol ditambahkan NitraVer 5 Nitrate (reagen kit). Sampel tersebut kemudian ditempatkan pada cell holder hingga terbaca nilai serapannya. Setelah itu, masukan nilai ke dalam persamaan kurva standar nitrat sebagai berikut:

Nitrat $=\frac{\text { nilail mendekati }}{\text { nilai absorbansi }} \times$ konsentrasi

Dari hasil pengukuran kemudian didapatkan persamaan analisis regresi yang digunakan untuk menentukan kadar nitrat yakni:

$$
y=0.026 x+0.026
$$

Pengukuran TSS dilakukan dengan menggunakan kertas saring yang telah dibilas akuades dan kemudian dioven hingga mencapai berat konstan sehingga dapat diketahui berat awalnya. Sampel air kemudian disaring dengan menggunakan kertas saring dan hasil dari penyaringan tersebut kemudian dioven kembali dengan suhu $103^{\circ} \mathrm{C}$ sampai dengan $105^{\circ} \mathrm{C}$ selama $1 \mathrm{jam}$. Setelah itu, kertas ditimbang berat akhirnya.

TSS $=\frac{(\mathrm{y}-\mathrm{x}) \mathrm{x} 1000}{\text { Volume sampel }(\mathrm{ml})}$

Keterangan:

$\mathrm{y}=$ berat kertas saring + residu $\quad \mathrm{x}=$ berat kertas saring

Pengukuran

Pengukuran kadar klorofil- $\alpha$ dilakukan dengan cara menempatkan hasil penyaringan air dengan menggunakan kertas saring. Kertas saring tersebut kemudian diberi aseton $90 \%$ dan didiamkan selama 24 jam. Selanjutnya, sampel diletakkan pada sentrifuge dan diputar dengan kecepata $1 \mathrm{rpm}$ untuk memisahkan suspensi. Setelah itu, pembacaan nilai klorofil menggunakan alat spektrofotometer.

\section{Analisa data}

Identifikasi plankton dilakukan dengan menggunakan mikroskop perbesaran 4x10 dengan memasukkan $1 \mathrm{ml}$ sampel ke dalam Sedgewick Rafter. Proses perhitungan dilakukan dengan pengulangan sebanyak 3 kali dengan metode APHA. Identifikasi plankton dilakukan dengan pustaka dari Yamaji (1984), Sachlan (1982), van Vuuren et al. (2006) dan Bellinger dan Sigee (2010).

\section{Kelimpahan plankton}

Perhitungan jumlah fitoplankton per liter dihitung dengan menggunakan rumus APHA, AWWA, WPCF (2005) dalam Hartoko (2013) yakni sebagai berikut:

$\mathrm{N}=\frac{\mathrm{T}}{\mathrm{L}} \times \frac{\mathrm{P}}{\mathrm{p}} \times \frac{\mathrm{V}}{\mathrm{v}} \times \frac{1}{\mathrm{w}}$

Keterangan:

$\mathrm{N}=$ Jumlah plankton per liter

$\mathrm{T}=$ Luas gelas penutup $\left(\mathrm{mm}^{2}\right)$

$\mathrm{L}=$ Luas lapang pandang mikroskop $\left(\mathrm{mm}^{2}\right)$

$\mathrm{P} \quad=$ Jumlah plankton yang tercacah

$\mathrm{p} \quad=$ Jumlah lapang pandang yang diamati

Pada perhitungan kelimpahan, diameter lapang pandang mikroskop yang dipakai yakni $1.98 \mathrm{~mm}^{2}$ atau dibulatkan yakni $2 \mathrm{~mm}$ yang didapatkan dari hasil pengukuran pada lensa okuler. Dari hasil tersebut luas lapang pandang mikroskop dihitung dengan perhitungan luas lingkaran yakni $L=\pi \mathrm{r}^{2}$. Dari perhitungan tersebut didapatkan nilai luas lapang pandang mikroskop yakni $3.14 \mathrm{~mm}^{2}$. 


\section{Indeks dominasi}

Menurut Odum (1998) dalam Ersa et al. 2014, untuk mengetahui adanya dominasi tertentu di perairan dapat digunakan indeks dominasi dengan persamaan berikut:

$\mathrm{D}=\left(\frac{\mathrm{Ni}}{\mathrm{N}}\right)^{\mathrm{T}}$

Keterangan :

$\mathrm{D}=$ Indeks dominasi $\mathrm{N}=$ Jumlah total individu

$\mathrm{Ni}=$ Jumlah individu tiap jenis

SI (Saprobik Indeks) dan TSI (Tropik Saprobik Indeks)

Untuk menghitung saprobitas perairan menggunakan analisis TROSAP yang nilainya ditentukan oleh Saprobik Indeks (SI) dan Tropik Saprobik Indeks (TSI) dengan formulasi Persoone dan De Pauw (1983) dalam Suryanti (2008) adalah sebagai berikut:

$\mathrm{SI}=\frac{1 \mathrm{C}+3 \mathrm{D}+1 \mathrm{~B}-3 \mathrm{~A}}{1 \mathrm{~A}+1 \mathrm{~B}+1 \mathrm{C}+1 \mathrm{D}}$

Keterangan :

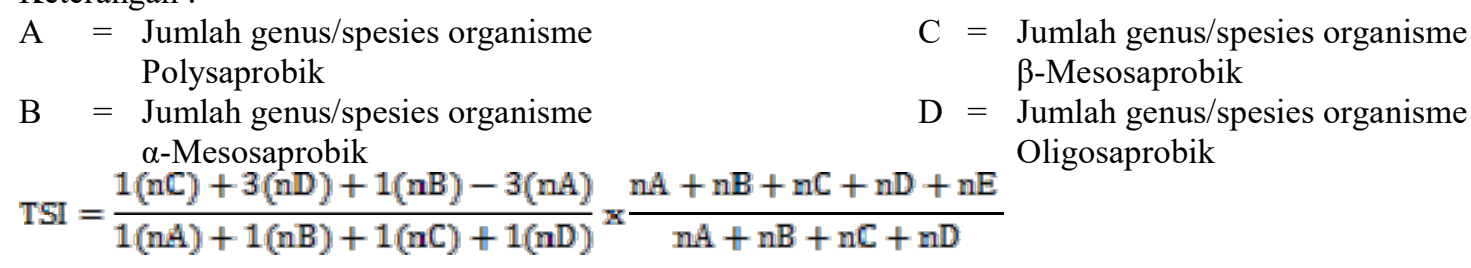

Keterangan :

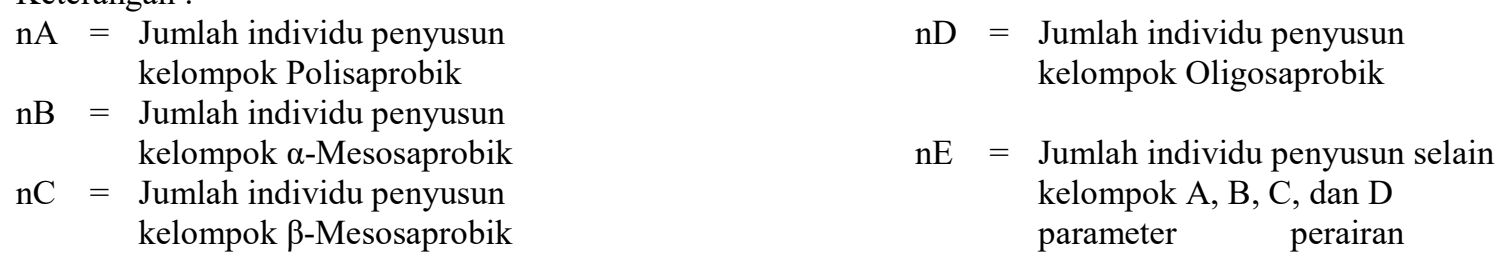

3. HASIL DAN PEMBAHASAN

A. Hasil

Gambaran umum lokasi penelitian

Lokasi penelitian terletak pada Desa Pidodo Kulon, Dusun Palangsari, Kecamatan Patebon, Kabupaten Kendal. Luas Daerah Aliran Sungai (DAS) Bodri mencapai $610.8 \mathrm{~km}^{2}$. Berdasarkan pada letak geografisnya, Sungai Bodri terletak pada garis lintang 6 $6^{\circ} 1^{\prime} 33.64^{\prime} \mathrm{S}$ dan garis bujur $110^{\circ} 10^{\prime} 36.39^{\prime}$ T. Luas DAS Bodri hingga muara sungai yakni sekitar $610.8 \mathrm{~km}^{2}$ yang terbagi atas 5 sub DAS, yaitu Sub DAS Lutut, Sub DAS Logung, Sub DAS Putih, Sub DAS Blorong dan Sub DAS Bodri Hilir. Desa Pidodo Kulon merupakan desa terdekat dari Sungai Bodri yang mempunyai penduduk sekitar 3.049 jiwa dengan luas wilayah $\pm 532,20 \mathrm{Ha}$

Sungai Bodri dikelilingi oleh kawasan pertanian, pertambakan dan pemukiman warga. Aktivitas masyarakat di sekitar kawasan Sungai Bodri terdiri dari kegiatan perikanan seperti, penangkapan dan pengolahan ikan. Kegiatan pengolahan yang dilakukan masyarakat merupakan industri dengan skala rumah tangga namun, limbah yang dihasilkan dapat mengakibatkan penambahan bahan organik secara signifikan. Selain itu, pada setiap tepian Sungai Bodri banyak terdapat nelayan yang bersandar melakukan kegiatan perebusan rajungan dikarenakan lokasi fishing ground rajungan yang dekat dari Sungai Bodri.

Saprobitas, kelimpahan dan indeks dominasi

Tabel 1. Nilai Indeks Saprobitas (SI) dan Tropik Saprobik Indeks (TSI) Saat Pasang Surut di Setiap Stasiun

\begin{tabular}{ccccc}
\hline \multirow{2}{*}{ Stasiun } & \multicolumn{2}{c}{ SI } & \multicolumn{2}{c}{ TSI } \\
\cline { 2 - 5 } & Pasang & Surut & Pasang & Surut \\
\hline 1 & 1.00 & 0.88 & 0.99 & 1.04 \\
2 & 1.20 & 1.29 & 2.39 & 2.36 \\
3 & 0.75 & 1.00 & 2.18 & 1.98 \\
4 & 1.00 & 1.00 & 2.56 & 2.30 \\
\hline
\end{tabular}

Dari hasil perhitungan nilai SI diperoleh nilai pada saat pasang berada pada kisaran $0.75-1.20$ dan pada saat surut pada kisaran 0.88-1.29 yang menyatakan bahwa perairan dalam kondisi $\beta$-Mesosaprobik hingga $\beta$ Mesosaprobik/Oligosaprobik. Sedangkan, nilai TSI berada pada kisaran 0.99-2.56 pada saat pasang dan 1.04 hingga 2.36 yang menyatakan bahwa perairan berada pada kondisi $\beta$-Mesosaprobik hingga Oligosaprobik. 
Dari hasil penelitian terdapat 65 genera dan 115 spesies yang ditemukan di seluruh stasiun yang berada di sekitar Muara Sungai Bodri yang akan dijelaskan pada Tabel 2. dan Tabel 3.

Tabel 2. Kelimpahan dan dominasi plankton pada saat pasang $(\mathrm{Ind} / \mathrm{L})$

\begin{tabular}{|c|c|c|c|c|}
\hline Spesies & St. 1 & St. 2 & St. 3 & St. 4 \\
\hline \multicolumn{5}{|l|}{ Polisaprobik } \\
\hline Rotaria neptunia & 0 & 0 & 0 & 32 \\
\hline Spirulina sp. & 0 & 0 & 32 & 0 \\
\hline Streptococcus & 32 & 0 & 64 & 32 \\
\hline $\begin{array}{l}\text { margaritaceus } \\
\boldsymbol{\alpha} \text {-Mesosaprobik }\end{array}$ & & & & \\
\hline $\begin{array}{l}\text { Chaetoceros } \\
\text { densus }\end{array}$ & 0 & 0 & 0 & 64 \\
\hline C. diversus & 0 & 0 & 320 & 32 \\
\hline C. eibenii & 0 & 0 & 0 & 32 \\
\hline $\begin{array}{l}\text { Cyclotella } \\
\text { meneghiniana }\end{array}$ & 1312 & 864 & 32 & 32 \\
\hline $\begin{array}{l}\text { Nitzschia } \\
\text { acicularis }\end{array}$ & 128 & 352 & 0 & 0 \\
\hline N. amphibia & 96 & 0 & 32 & 32 \\
\hline N. palea & 864 & 160 & 0 & 0 \\
\hline $\begin{array}{l}\text { Navicula } \\
\text { tripunctata }\end{array}$ & 288 & 32 & 0 & 0 \\
\hline $\begin{array}{l}\text { Rhizosolenia } \\
\text { imbricata }\end{array}$ & 0 & 0 & 32 & 0 \\
\hline R. indica & 0 & 0 & 32 & 128 \\
\hline R. setigera & 0 & 0 & 256 & 64 \\
\hline $\begin{array}{l}\text { R. styliformis } \\
\boldsymbol{\beta} \text {-Mesosaprobik }\end{array}$ & 0 & 0 & 32 & 32 \\
\hline Asterionella sp. & 32 & 128 & 704 & 0 \\
\hline Ceratium fusus & 0 & 0 & 96 & 32 \\
\hline C. macroceros & 0 & 0 & 0 & 32 \\
\hline C. massiliense & 0 & 0 & 0 & 32 \\
\hline $\begin{array}{l}\text { Coscinodiscus } \\
\text { lacustris }\end{array}$ & 96 & 96 & 32 & 0 \\
\hline $\begin{array}{l}\text { Gyrosigma } \\
\text { accuminatum }\end{array}$ & 0 & 32 & 0 & 0 \\
\hline Melosira varians & 0 & 0 & 0 & 32 \\
\hline Nauplius sp. & 0 & 32 & 0 & 128 \\
\hline $\begin{array}{l}\text { Synedra ulna } \\
\text { Oligosaprobik }\end{array}$ & 16096 & 1184 & 96 & 0 \\
\hline $\begin{array}{l}\text { Skeletonema } \\
\text { costatum }\end{array}$ & 0 & 2112 & 960 & 160 \\
\hline S. subsalum & 320 & 0 & 0 & 0 \\
\hline S. tropicum & 0 & 0 & 96 & 64 \\
\hline $\begin{array}{l}\text { Tabellaria } \\
\text { flocculosa }\end{array}$ & 32 & 0 & 0 & 0 \\
\hline Lain-lain & 448 & 1632 & 2400 & 1248 \\
\hline$\sum=$ & 19744 & 6624 & 5184 & 2208 \\
\hline$\overline{\mathrm{S}}=$ & 16 & 18 & 37 & 32 \\
\hline $\mathrm{C}=$ & 0.659 & 0.197 & 0.107 & 0.073 \\
\hline
\end{tabular}

Tabel 3. Kelimpahan dan dominasi plankton pada saat surut (Ind/L)

\begin{tabular}{|c|c|c|c|c|}
\hline Spesies & St. 1 & St. 2 & St. 3 & St. 4 \\
\hline Polisaprobik & & & & \\
\hline Streptococcus & 32 & 832 & 256 & 32 \\
\hline $\begin{array}{l}\text { margaritaceus } \\
\boldsymbol{\alpha} \text {-Mesosaprobik }\end{array}$ & & & & \\
\hline $\begin{array}{l}\text { Chaetoceros } \\
\text { constrictus }\end{array}$ & 0 & 0 & 416 & 64 \\
\hline C. convolatum & 0 & 32 & 0 & 0 \\
\hline C. danicus & 0 & 64 & 352 & 512 \\
\hline C. densus & 0 & 64 & 0 & 0 \\
\hline C. diversus & 0 & 64 & 1408 & 0 \\
\hline C. eibenii & 0 & 0 & 448 & 0 \\
\hline C. mиelleri & 0 & 0 & 32 & 0 \\
\hline C. nipponicum & 0 & 0 & 0 & 160 \\
\hline C. pendulus & 0 & 32 & 64 & 192 \\
\hline $\begin{array}{l}\text { C. } \\
\text { pseudocrinitum }\end{array}$ & 0 & 0 & 0 & 96 \\
\hline $\begin{array}{l}\text { Cyclotella } \\
\text { meneghiniana }\end{array}$ & 5440 & 0 & 128 & 224 \\
\hline $\begin{array}{l}\text { Nitzschia } \\
\text { acicularis }\end{array}$ & 256 & 512 & 0 & 0 \\
\hline N. amphibia & 640 & 576 & 64 & 160 \\
\hline $\begin{array}{l}\text { Navicula } \\
\text { tripunctata }\end{array}$ & 2112 & 0 & 0 & 0 \\
\hline $\begin{array}{l}\text { Oscillatoria } \\
\text { formosa }\end{array}$ & 32 & 64 & 32 & 0 \\
\hline $\begin{array}{l}\text { Stephanodiscus } \\
\text { hantzscii }\end{array}$ & 64 & 2048 & 0 & 0 \\
\hline $\begin{array}{l}\text { Rhizosolenia } \\
\text { alata }\end{array}$ & 0 & 0 & 96 & 0 \\
\hline R. imbricata & 0 & 0 & 64 & 0 \\
\hline R. indica & 0 & 0 & 96 & 0 \\
\hline $\begin{array}{l}\text { R. hebetata var. } \\
\text { hiemalis }\end{array}$ & 0 & 0 & 64 & 704 \\
\hline R. setigera & 0 & 1376 & 768 & 512 \\
\hline $\begin{array}{l}\text { R. styliformis } \\
\boldsymbol{\beta} \text {-Mesosaprobik }\end{array}$ & 0 & 0 & 64 & 384 \\
\hline Asterionella sp. & 224 & 3360 & 4768 & 5760 \\
\hline Ceratium breve & 0 & 0 & 0 & 32 \\
\hline C. fusus & 0 & 0 & 128 & 160 \\
\hline C. pentagonum & 0 & 0 & 0 & 32 \\
\hline $\begin{array}{l}\text { Coscinodiscus } \\
\text { lacustris }\end{array}$ & 512 & 0 & 0 & 0 \\
\hline $\begin{array}{l}\text { Cosmarium } \\
\text { impressulum }\end{array}$ & 96 & 0 & 0 & 0 \\
\hline $\begin{array}{l}\text { Eucampia } \\
\text { zoodiscus }\end{array}$ & 0 & 32 & 32 & 32 \\
\hline $\begin{array}{l}\text { Gyrosigma } \\
\text { accuminatum }\end{array}$ & 96 & 96 & 160 & 160 \\
\hline Nauplius sp. & 0 & 0 & 352 & 256 \\
\hline
\end{tabular}


Lanjutan Tabel 3. Kelimpahan dan dominasi plankton pada saat pasang (Ind/L)

\begin{tabular}{lcccc}
\hline Spesies & St. 1 & St. 2 & St. 3 & St. 4 \\
\hline $\begin{array}{l}\text { Scenedesmus } \\
\text { quadricauda }\end{array}$ & 0 & 0 & 32 & 0 \\
$\begin{array}{l}\text { Synedra ulna } \\
\text { Oligosaprobik }\end{array}$ & 72416 & 5376 & 256 & 352 \\
$\begin{array}{l}\text { Skeletonema } \\
\text { costatum }\end{array}$ & 0 & 11104 & 2432 & 2016 \\
$\begin{array}{l}\text { S. subsalum } \\
\text { S. tropicum }\end{array}$ & 736 & 0 & 0 & 0 \\
$\begin{array}{l}\text { Pinnularia } \\
\text { nobilis }\end{array}$ & 0 & 15392 & 96 & 96 \\
$\begin{array}{l}\text { Phacus pyrum } \\
\text { Tabellaria }\end{array}$ & 128 & 32 & 0 & 0 \\
flocculosa & 64 & 32 & 0 & 0 \\
Lain-lain & 0 & 64 & 0 & 0 \\
\hline $\begin{array}{l}\sum= \\
\text { S }=\end{array}$ & 2336 & 10432 & 6592 & 12992 \\
C= & 85184 & 51616 & 18976 & 24928 \\
\hline
\end{tabular}

\section{Kualitas air}

Hasil pengukuran kualitas perairan disajikan dalam tabel sebagai berikut:

Tabel 4. Hasil pengukuran kualitas perairan pada saat pasang dan surut

\begin{tabular}{|c|c|c|c|c|c|c|c|c|c|}
\hline \multirow{2}{*}{$\begin{array}{l}\text { Kualitas } \\
\text { Perairan }\end{array}$} & \multicolumn{4}{|c|}{ Pasang } & \multicolumn{4}{|c|}{ Surut } & \multirow[t]{2}{*}{ Pustaka } \\
\hline & St. 1 & St.2 & St. 3 & St. 4 & St. 1 & St.2 & St. 3 & St. 4 & \\
\hline Suhu & 30 & 29 & 30.67 & 31 & 30.33 & 29.67 & 30.67 & 30.33 & $20-35$ (Effendi, 2003) \\
\hline $\mathrm{pH}$ & 6 & 6.3 & 6 & 6 & 6 & 6 & 6 & 6 & $6.5-9$ (Boyd, 1991) \\
\hline DO & 5.24 & 5.24 & 4.57 & 5.64 & 10.08 & 7.26 & 8.06 & 6.85 & $6.5-8.4$ (Asdak, 2002) \\
\hline $\begin{array}{l}\text { Kecepatan } \\
\text { Arus }\end{array}$ & 0.066 & 0.249 & 0.146 & 0.074 & 0.101 & 0.238 & 0.151 & 0.176 & - \\
\hline Kecerahan & 39 & 46.42 & 50.67 & 56.5 & 0 & 41.5 & 55 & 86.5 & - \\
\hline Kedalaman & 149.67 & 92.33 & 694.67 & 770 & 126 & 104 & 554 & 701 & - \\
\hline Salinitas & 0 & 7 & 94 & 23.67 & 0 & 19 & 30.67 & 30 & $0.5-35$ (Barnes, 1976) \\
\hline Klorofil- $\alpha$ & 0.0022 & 0.0074 & 0.0018 & 0.0007 & 0.0017 & 0.0002 & 0.0009 & 0.0017 & \\
\hline Nitrat & 0.13 & 0.19 & 0.06 & 0.12 & 0.12 & 0.24 & 0.08 & 0.27 & $\begin{array}{c}0.9-3.5 \\
\text { (Wardoyo, 1982) }\end{array}$ \\
\hline TSS & 0.8 & 1.6 & 5 & 4.8 & 1.6 & 1.8 & 5 & 6.4 & $<25$ (Effendi, 2003) \\
\hline
\end{tabular}

\section{B. Pembahasan}

Indeks Saprobitas (SI) dan Tropik Saprobik Indeks

Nilai SI pada tiap stasiun berada pada kisaran 0.75 - 1.29 dimana perairan berada pada skala $\beta$-Mesosaprobik hingga $\beta$-Mesosaprobik/Oligosaprik. Dari hasil pengukuran TSI didapatkan nilai 0.99 - 2.56 dimana perairan berada pada skala $\beta$-Mesosaprobik hingga Oligosaprobik. Nilai saprobitas didapatkan dari hasil pengukuran yang didapatkan dari pengamatan indikator perairan pada tiap-tiap stasiun. Dari kedua parameter tersebut dapat disimpulkan bahwa perairan Muara Sungai Bodri berada pada kisaran $\beta$-Mesosaprobik yang menyatakan bahwa perairan berada pada tingkat pencemaran ringan sampai sedang. Hal ini sesuai dengan pernyataan Pantle dan Buck (1955) dalam Basmi (2000) yang menyatakan bahwa $\beta$-Mesosaprobik merupakan saprobitas perairan yang tingkat pencemarannya ringan sampai sedang, kandungan oksigen terlarut (DO) dalam perairan tinggi, bakteri sangat menurun., menghasilkan produk akhir nitrat. Fitoplankton didominasi oleh Chlorophyceaedan Diatom, serta Euglenophyceae mulai jarang/menghilang, dengan kandungan oksigen terlarut mulai meningkat. Menurut Wijaya dan Riche (2009), kategori $\beta$-Mesosaprobik memiliki oksigen terlarut (DO) yang tinggi, bakteri lebih kecil daripada $\alpha$-Mesosaprobik dan pada kondisi ini ammonia (HNO3) telah menghasilkan produk akhir yaitu Nitrat (NH3'). Pada kategori Oligosaprobik bahan organik sudah sempurna terjadi penguraian, oksigen terlarut (DO) tinggi dan jumlah bakteri sangat rendah.

\section{Kelimpahan plankton}

Berdasarkan hasil penelitian, kelimpahan rata-rata pada Stasiun 1 hingga stasiun 4 berada pada kisaran 2208 hingga 85184. Kelimpahan plankton pada Stasiun 2 hingga Stasiun 4 pada saat pasang termasuk ke dalam kategori 
mesotrofik. Pada Stasiun 1 hingga Stasiun 4 pada saat surut dan Stasiun 1 pada saat pasang termasuk ke dalam kategori eutrofik. Perbedaan kelimpahan plankton pada masing-masing stasiun diakibatkan oleh pengaruh bahan organik dan faktor nutrien perairan yang konsentrasinya berbeda di setiap stasiun. Selain itu, perbedaan waktu pengukuran yakni pasang dan surut mempunyai peran persebaran bahan organik yang terbawa melalui sungai. Menurut Basmi (1987) dalam Indriany (2005), eutrofik merupakan kelimpahan plankton $>15.000$ ind/L dengan ciri-ciri perairan memiliki nilai kecerahan 0-2 meter, perairan berwarna hijau kareana kepadatan plankton tinggi dan semakin dalam perairan maka semakin berkurang kandungan oksigen dan mesotrofik merupakan kelimpahan plankton $2.000-15.000$ ind/L merupakan perairan peralihan antara kedua sifat eutrofik dan oligotrofik.

\section{Indeks dominasi}

Dari hasil penelitian, indeks dominasi berkisar antara $0.1042-0.7313$. Kriteria indeks dominasi menurut Odum (1993) dalam Meiriyani et al. (2011) yakni $0<\mathrm{C} \leq 0.5=$ Tidak ada spesies/genus yang mendominasi dan $0.5<$ $\mathrm{C}<1=$ Terdapat spesies/genus yang mendominasi. Dari pernyataan tersebut, dominasi spesies/genus terjadi pada Stasiun 1 dan Stasiun 4 pada saat pasang. Nilai indeks dominasi rendah pada yakni $<0.5$ pada Stasiun 2, Stasiun 3 dan Stasiun 4 pada saat surut menunjukkan tidak adanya dominasi spesies/genus yang menunjukkan bahwa perairan muara dan laut tidak terkena dampak dominasi spesies yang menandakan bahwa kemapuan muara dalam memanfaatkan masukan bahan organik yang berasal dari sungai sangat baik atau beban bahan organik hanya terakumulasi pada bagian muara dan dimanfaatkan untuk pertumbuhan fitoplankton yang berasosiasi di muara.

\section{Kualitas air}

Dari hasil pengamatan diperoleh nilai suhu $29-31^{\circ} \mathrm{C}$ yang masih dalam skala optimum bagi kehidupan fitoplankton. Letak perbedaan pengukuran antara pasang dan surut terdapat pada faktor cuaca dan intensitas cahaya matahari. Selain itu, pengadukan massa air pada wilayah laut cenderung berpengaruh terhadap fluktuasi suhu dimana panas yang masuk ke dalam badan air disebarkan secara vertikal dan horizontal pada kedalaman yang dapat ditembus cahaya. Menurut Hutabarat dan Evans (1985) dalam Purwanti et al. (2011) suhu perairan muara yaitu berkisar antara 15 - 35 C. Menurut Widyaprasetya (1999) dalam Wahikun (2016), ada keterkaitan antara suhu dengan fenomena upwelling dengan klorofil dan kelimpahan. Bahwa plankton yang tersangkut oleh massa air dingin dan hangat akan terakumulasi pada zona front dan area konvergen.

$\mathrm{pH}$ air dalam pengukuran pasang dan surut relatif pada $\mathrm{pH} 6$ - 7 dimana perairan masih dalam skala yang baik bagi pertumbuhan plankton. Nilai tertinggi terjadi pada Stasiun 2 ulangan ke-3 pada lokasi muara yakni 7 . Nilai pengukuran berada pada nilai yang konstan dikarenakan penggunaan kertas $\mathrm{pH}$ dinilai kurang tepat dalam penelitian. Menurut Effendi (2003), batas toleransi organisme terhadap perairan $\mathrm{pH}$ bervariasi tergantung pada suhu, oksigen terlarut dan kandungan garam-garam ionik di dalam perairan. Kebanyakan perairan alami mempunyai $\mathrm{pH}$ berkisar antara 6 - 9 dan sebagian besar biota perairan sensitif terhadap perubahan $\mathrm{pH}$ dan menyukai nilai $\mathrm{pH}$ sekitar $7-8.5$.

Kandungan DO tertinggi yakni pada Stasiun 1 saat surut dengan nilai rata-rata $10.08 \mathrm{mg} / \mathrm{L}$ dan terendah pada Stasiun 3 pada saat pasang dengan nilai rata-rata 4.57. Perbedaan kandungan oksigen terlarut pada saat pasang dan surut disebabkan oleh pengadukan massa air oleh arus, suhu perairan dan kandungan fitoplankton pada perairan yang menghasilkan oksigen dalam perairan dari proses fotosintesis. Menurut Ketentuan UNESCO/WHO/UNEP (1992) dalam Suryono et al. (2010) bahwa konsentrasi oksigen terlarut kurang dari $4 \mathrm{mg} / \mathrm{l}$ dapat menimbulkan efek yang kurang menguntungkan bagi hampir semua organisme aquatik, jika kadar oksigen terlarut yang kurang dari 2 mg/L dapat menyebabkan kematian ikan.

Berdasarkan hasil pengamatan, kecepatan arus pada Muara Sungai Bodri berkisar antara $0.1-0.24 \mathrm{~m} / \mathrm{s}$ pada saat pasang dan $0.05-0.15 \mathrm{~m} / \mathrm{s}$ pada saat surut. Nilai tertinggi didapatkan pada saat pasang pada stasiun 2 yang terletak pada Muara Sungai Bodri. Menurut Harahap dalam Ihsan (2009), kecepatan arus dapat dibedakan dalam 4 kategori yakni kecepatan arus $0-0.25 \mathrm{~m} / \mathrm{dtk}$ yang disebut arus lambat, kecepatan arus $0.25-0.50 \mathrm{~m} / \mathrm{dtk}$ yang disebut arus sedang, kecepatan arus $0.50-1 \mathrm{~m} / \mathrm{dtk}$ yang disebut arus cepat dan kecepatan arus diatas $1 \mathrm{~m} / \mathrm{dtk}$ yang disebut arus sangat cepat. Dari pernyataan diatas, dapat disimpulkan keadaan arus selama penelitian di Muara Sungai Bodri termasuk ke dalam arus lambat.

Hasil pengamatan kecerahan pada saat pasang dan surut didapatkan nilai tertinggi pengukuran terjadi pada Stasiun 3 saat pasang dengan nilai rata-rata $56.5 \mathrm{~cm}$ dan nilai terendah terjadi pada Stasiun 1 saat surut dengan nilai rata-rata 0 . Pada stasiun 1 kecerahan berada pada nilai 0 dikarenakan tidak ada cahaya matahari dikarenakan hari telah gelap. Nilai kecerahan dipengaruhi oleh penetrasi cahaya yang masuk ke dalam perairan. Menurut Effendi (2003) perairan dengan nilai kecerahan kurang dari $200 \mathrm{~cm}$ termasuk perairan eutrofik. Kedalaman tertinggi didapatkan pada Stasiun 4 pada saat pasang dengan nilai $770 \mathrm{~cm}$ dimana posisi pengukuran dilakukan pada ekosistem laut. Sedangkan, kedalaman terendah didapatkan pada Stasiun 2 pada saat pasang dengan nilai $92.33 \mathrm{~cm}$. Pada daerah Muara Sungai Bodri kedalaman perairan rendah diakibatkan oleh adanya proses sedimentasi pada bagian muara sehingga substrat perairan dengan jangka waktu yang lama akan naik secara perlahan. Hal ini disebabkan oleh keadaan muara yang terlalu banyak menampung bahan organik dari aktivitas manusia di sekitar Sungai Bodri.

Dari hasil pengamatan nilai salinitas terjadi pada stasiun 3 pada saat pasang dengan nilai 31.33 ppm. Sedangkan nilai terendah terjadi pada Stasiun 1 pada saat pasang dan surut yakni dengan nilai 0 ppm. Nilai salinitas pada tiap stasiun didasarkan pada kondisi air yang mengalir di dalamnya sebab air tawar tidak memiliki kandungan garam ataupun ion-ion yang dapat membentuk garam sehingga nilai salinitas akan berada pada posisi 0 . Variasi salinitas dapat mempengaruhi kehidupan berbagai jenis plankton dalam suatu perairan. Di perairan pantai bersalinitas rendah 
komunitas plankton lebih tinggi daripada perairan yang letaknya jauh dari pantai yang bersalinitas tinggi terutama dalam menentukan suksesi jenisnya (Chua, 1970 dalam Simanjuntak, 2009).

Kandungan TSS paling tinggi didapatkan pada stasiun 4 saat surut dengan nilai $6.4 \mathrm{mg} / \mathrm{L}$. Sedangkan, nilai terendah pengukuran berada pada stasiun 1 pada saat pasang dengan nilai $0.8 \mathrm{mg} / \mathrm{L}$. Nilai TSS dipengaruhi oleh substrat maupun bahan organik yang terangkat pada badan air yang disebabkan oleh pengadukan massa air dan masukan bahan organik dari sungai.

Dari hasil pengamatan diketahui bahwa nilai Nitrat perairan tertinggi berada di Stasiun 4 dan terjadi pada saat surut dengan nilai sebesar $0.27 \mathrm{mg} / \mathrm{L}$. Sedangkan nilai terendah terjadi pada Stasiun 3 saat pasang dengan nilai 0.06 $\mathrm{mg} / \mathrm{L}$. Dari nilai tersebut, kandungan nitrat pada perairan Muara Sungai Bodri termasuk ke dalam perairan oligotrofik. Menurut Vollenweider (1968) dalam Effendi (2003) tingkat kesuburan oligotrofik memiliki kandungan nitrat antara 0 $1 \mathrm{mg} / \mathrm{L}$. Dari pernyataan tersebut kandungan klorofil pada Muara Sungai Bodri termasuk ke dalam kategori oligotrofik. Dari pernyataan tersebut dapat disimpulkan bahwa kandungan klorofil pada tiap stasiun berada pada perairan oligotrofik dengan pengecualian pada stasiun 2 saat pasang dimana kandungan klorofil berada pada nilai $7.4 \mathrm{~g} / \mathrm{L}$ yang menandakan perairan mesotrofik.

Hubungan antara SI dengan DO pada saat pasang menunjukkan korelasi lemah sedangkan pada saat surut menunjukkan korelasi sedang hingga kuat serta, garis linear menunjukkan korelasi positif dengan pengecualian pada korelasi TSI dengan DO pada saat surut yang menunjukkan korelasi negatif. Hubungan SI dengan Nitrat pada saat pasang menunjukkan bahwa korelasi lemah terjadi pada hubugan antara TSI dengan nitrat pada saat pasang sedangkan, korelasi kuat terjadi pada hubungan antara SI dengan nitrat pada saat pasang dan surut dan TSI dengan nitrat pada saat pasang. Korelasi yang terjadi antara SI, TSI terhadap nitrat menunjukkan korelasi positif. Menurut Sitorus (2009) dalam Syahfitri (2014), konsentrasinya di dalam perairan akan semakin bertambah bila semakin dekat dari titik pembuangan, namun akan semakin berkurang bila jauh dari titik pembuangan yang disebabkan aktivitas dari mikroorganisme yang akan mengoksidasi amonium menjadi nitrit yang akhirnya menjadi nitrat.

Dari hasil tersebut, korelasi kuat terjadi pada SI dengan TSS pada saat pasang, TSI dengan TSS pada saat pasang sedangkan, korelasi lemah terjadi pada hubungan SI dengan TSS pada saat surut dan TSI dengan TSS pada saat surut. Korelasi positif terjadi pada hubungan antara TSI dengan TSS sedangkan, korelasi negatif terjadi pada hubugan antara SI dengan TSS. Pada saat pasang dan surut, hubungan antara SI dengan klorofil- $\alpha$ menunjukkan korelasi kuat dan hubungan antara TSI dengan klorofil- $\alpha$ pada saat surut sedangkan, korelasi lemah terjadi pada hubungan antara TSI dengan klorofil- $\alpha$ pada saat pasang. Berdasarkan persamaan linear, korelasi positif terjadi pada saat pasang sedangkan, korelasi negatif terjadi pada hubungan antara SI dengan klorofil- $\alpha$ dan hubungan antara TSI dengan klorofil- $\alpha$ pada saat surut.

Perbedaan korelasi dengan klorofil- $\alpha$ menunjukkan bahwa korelasi kuat antara SI dan TSI terjadi pada saat surut. Hal ini disebabkan oleh beberapa faktor seperti kondisi perairan, masukan bahan organik dan parameter lingkungan. Aryawati dan Thoha (2011) menyatakan bahwa parameter lingkungan yang mempengaruhi kelimpahan fitoplankton dan kandungan klorofil- $\alpha$ antara lain adalah intensitas cahaya, suhu, salinitas, arus, oksigen terlarut dan nutrien (terutama nitrat, fosfat dan silikat). Tidak adanya hubungan antara kelimpahan dengan parameter lingkungan lainnya kemungkinan diakibatkan oleh adanya dominasi oleh beberapa marga saja di beberapa stasiun selain juga dikarenakan tidak adanya perbedaan parameter tersebut di stasiun penelitian (Ismunarti, 2013).
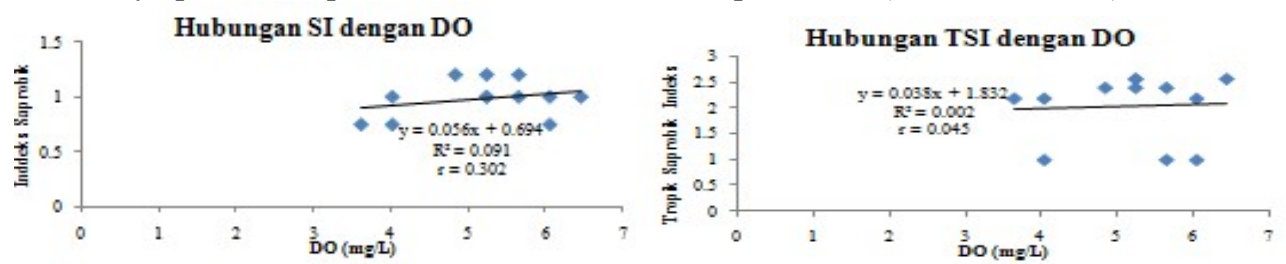

Gambar 2. Regresi Linear SI dan TSI dengan DO pada saat pasang
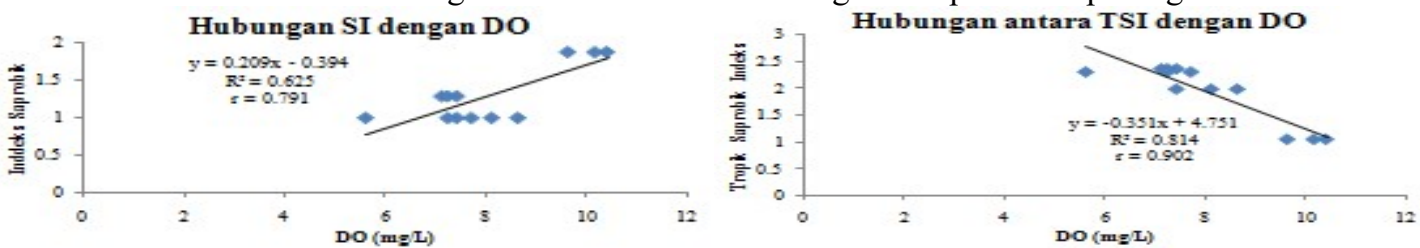

Gambar 3. Regresi Linear SI dan TSI dengan DO pada saat surut
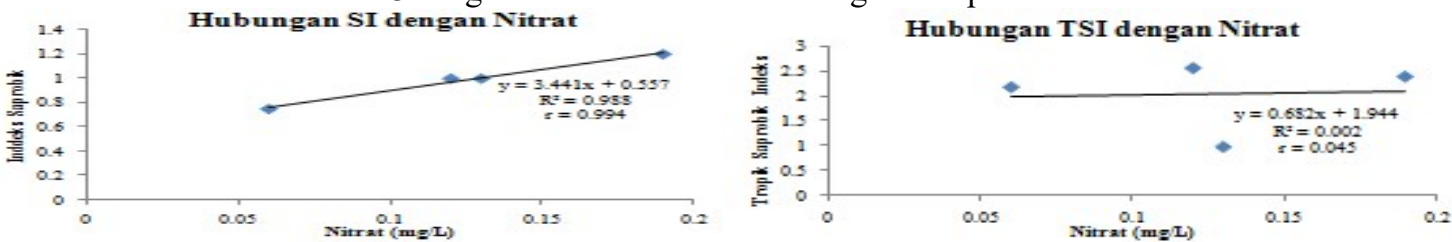

Gambar 4. Regresi Linear SI dan TSI dengan Nitrat pada saat pasang 

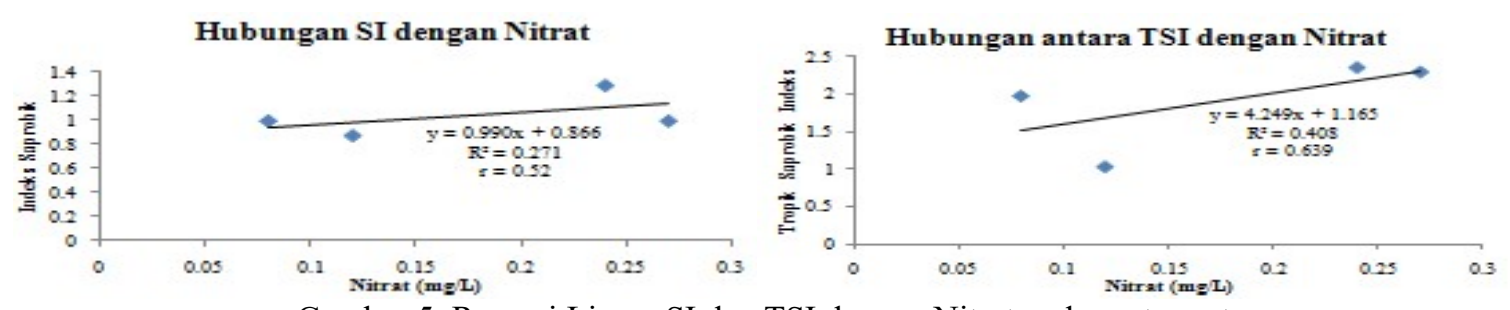

Gambar 5. Regresi Linear SI dan TSI dengan Nitrat pada saat surut
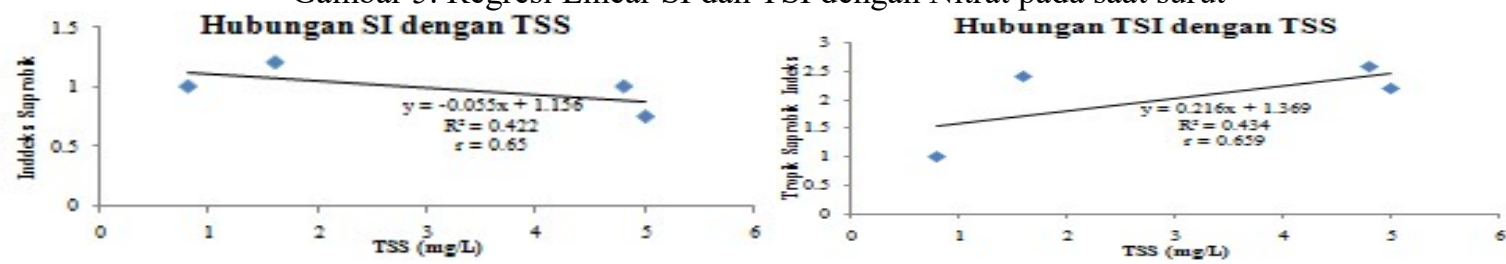

Gambar 6. Regresi Linear SI dan TSI dengan TSS pada saat pasang
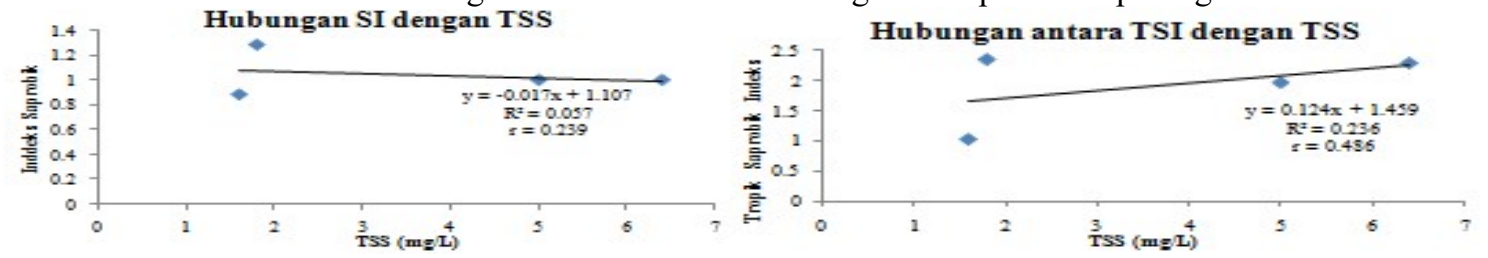

Gambar 7. Regresi Linear SI dan TSI dengan TSS pada saat surut
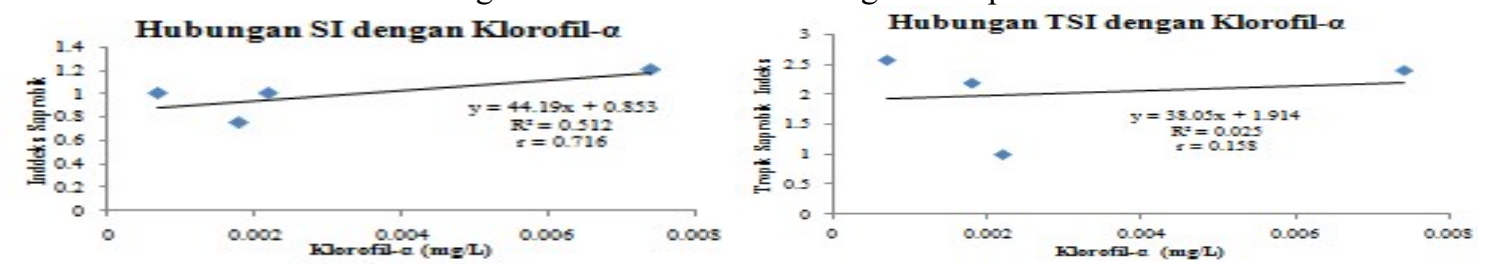

Gambar 8. Regresi Linear SI dan TSI dengan Klorofil- $\alpha$ pada saat pasang
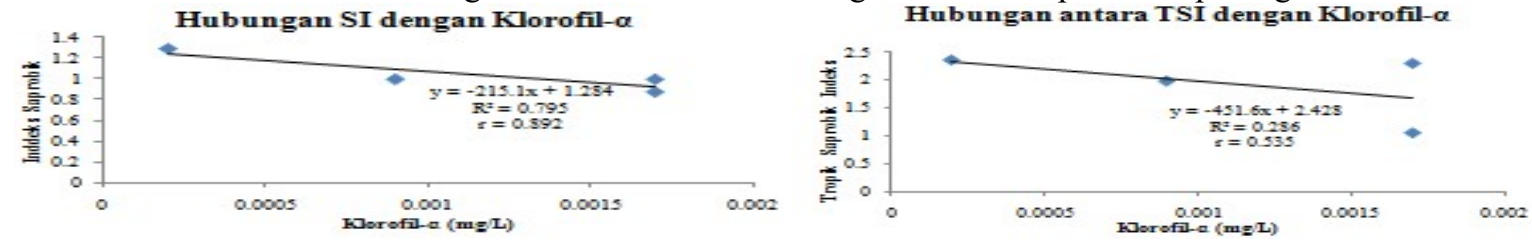

Gambar 9. Regresi Linear SI dan TSI dengan Klorofil- $\alpha$ pada saat surut

\section{KESIMPULAN}

Berdasarkan hasil penelitian dapat disimpulkan bahwa:

1. Nilai SI pada perairan berkisar antara 0.75 -1.29 yang menyatakan perairan dalam kondisi $\beta$-Mesosaprobik hingga $\beta$-Mesosaprobik/Oligosaprobik. dan nilai TSI antara 0.99 - 2.56 yang menyatakan perairan berada pada skala $\beta$-Mesosaprobik hingga Oligosaprobik;

2. Kandungan klorofil pada perairan Muara Sungai Bodri berada pada skala 0.0002-0.0074 mg/ml yang tergolong ke dalam kategori rendah hingga sedang; dan

3. Hubungan antara SI, TSI dan kualitas air yakni DO, TSS, Nitrat dan klorofil- $\alpha$ menunjukkan nilai positif dengan keeratan lemah pada saat pasang dan nilai positif negatif dengan keeratan kuat pada saat surut.

\section{DAFTAR PUSTAKA}

Abadi, Y. A., B. Suharto, dan J. B. Rahadi. 2014. Analisa Kualitas Perairan Sungai Klinter Nganjuk Berdasarkan Parameter Biologi (Plankton). Jurnal Sumberdaya Alam dan Lingkungan, 1(3): hlm 36-42.

Aryawati, R dan H. Thoha. 2011. Hubungan Kandungan Klorofil- $\alpha$ dan Kelimpahan Fitoplankton di Perairan Berau Kalimantan Timur. Maspari Journal, 02(2011): 89-94.

Basmi, J. 2000. Planktonologi Sebagai Indikator Pencemaran Perairan. Fakultas Perikanan dan Ilmu Kelautan. Institut Pertanian Bogor, Bogor, 60 hlm.

Cervetto,G., C. Mesones, and D. Calliari. 2002. Phytoplankton Biomass and its Relationship to Environmental Variables in a Disturbed Coastal Area of The Rio De La Plata Uruguay, before the New Sewage Collector System. Atlantica, 24(1): 45-54. 
Davies, P. 2004. Nutrient Processes and Chlorophyll in the Estuary and Plume of the Gulf of Papua. Continental Shelf Research 24:2317-2341.

Effendi, H. 2003. Telaah Kualitas Air Bagi Pengelolaan Sumber Daya dan Lingkungan Perairan. Kanisius, Yogyakarta, $249 \mathrm{hlm}$

Ersa, S. M. M., A. Suryanto dan Suryanti. 2014. Analisa Status Pencemaran dengan Indeks Saprobitas di Sungai Klampisan Kawasan Industri Candi, Semarang. Diponegoro Journal of Maquares. 3(4): 216-224.

Hartoko, A. 2013. Oceanographic Characters and Plankton Resources of Indonesia. Graha Ilmu. Yogyakarta. 166 hlm.

Hutabarat, S., P. Soedarsono dan I. Cahyaningtyas. 2013. Studi Analisa Plankton Untuk Menentukan Tingkat Pencemaran di Muara Sungai Babon Semarang. Journal of Management of Aquatic Resources, 2(03): 74-84.

Ihsan, N. 2009. Komposisi Hasil Tangkapan Sondong di Kelurahan Batu Teritip Kecamatan Sungai Sembilan Kota Dumai Provinsi Riau. [Skripsi]. Fakultas Perikanan dan Ilmu Kelautan Universitas Riau. Pekanbaru.. 57 hlm.

Indriany, M. 2005. Struktur Komunitas Diatom dan Dinoflagellata pada Beberapa Daerah Budidaya di Teluk Hurun, Lampung. [Skripsi]. Program Studi Biologi Universitas Negeri Jakarta. Jakarta. $125 \mathrm{hlm}$.

Ismunarti, D. H. 2013. Analisis Komponen Utama pada Hubungan Distribusi Spasial Komunitas Fitoplankton dan Faktor Lingkungan. Jurnal Ilmu Kelautan, 18(1): 14-19.

Meiriyani, F., T. Z. Ulqodry dan W. A. E. Putri. 2011. Komposisi dan Sebaran Fitoplankton di Perairan Muara Sungai Way Belau, Bandar Lampung. Maspari Journal 03(2011): 69-77.

Purwanti, S, R. Hariyati dan E. Wiryani. 2011. Komunitas Plankton pada Saat Pasang dan Surut di Perairan Muara Sungai Demaan Kabupaten Jepara. Laboratorium Ekologi dan Biosistematik. Universitas Diponegoro: 65-73.

Rahman, A. dan S. E. Purnamaningtyas. 2012. Kualitas Biologi Perairan Situ Cileunca Kabupaten Bandung Jawa Barat Berdasarkan Bioindikator Plankton.Jurnal Akuatika, 2(2): 136-144.

Simanjuntak, M. 2009. Hubungan Faktor Lingkungan Kimia, Fisika Terhadap Distribusi Plankton di Perairan Belitung Timur, Bangka Belitung. Jurnal Perikanan (J. Fish. Sci), XI(1): 31-45.

Suryanti. 2008. Kajian Tingkat Saprobitas di Muara Sungai Morodemak pada Saat Pasang Surut. Jurnal Saintek Perikanan, 4(1), 2008: 76-83.

Suryono, T. S. Sunanisari, E. Mulyana dan Rosidah. 2010. Tingkat Kesuburan dan Pencemaran Danau Limboto, Gorontalo. Jurnal Oseanologi dan Limnologi. 36(1): 49-61.

Syahfitri, T. A., H. Wahyuningsih dan R. Leidonald. 2014. Produktivitas Primer Perairan Estuati Berdasarkan Kandungan Klorofil- $\alpha$ di Kecamatan Talawi. Kabupaten Batu Bara. Jurnal Aquacoastmarine, 5(4): 11-19.

Teddlie, C. and F. Yu. 2007. Mixed Methods Sampling: A Typology with Examples. Journal of Mixed Method Research, 2007 1:77.

Wahikun. 2016. Radioaktivitas pada Perairan Pesisir Cilacap: Edisi 1. Deepublish, Yogyakarta, 81 hlm.

Wijaya, T. S. dan H. Riche. 2009. Struktur Komunitas Fitoplankton sebegai Bio Indikator Kualitas Perairan Danau Rawapening Kabupaten Semarang Jawa Tengah. Jurnal Anatomi Fisiologi, 19(1) (2011): 55-61. 